\title{
Knowledge, Atitude and Practice of Cultural Heritage Tourism among Domestic Tourist in Melaka World Heritage Site
}

\author{
Abd Rahman Roslan* \\ Department of Geography, Faculty of Arts and Social Science, University of Malaya
}

DOI: $10.36348 / \mathrm{sb} .2019 . v 05 i 12.016$

| Received: 14.12.2019 | Accepted: 22.12.2019 | Published: 28.12.2019

*Corresponding author: Abd Rahman Roslan

\section{Abstract}

Tourist interest in heritage and historic tourism site has been expanding and important nowadays. The declaration of Melaka as a World Heritage Site by UNESCO in July 2008 has made it one of the major tourist destination in Malaysia. This declaration has boosted the arrival of tourist not only from international tourists but domestic tourist too. The objective of this study are to find out about the knowledge of domestic tourist towards Melaka's historical background, attitude towards the preservation and conservation and tourist practice during visiting the heritage and historical site around Melaka city. A total of 263 respondents from domestic tourists travelling in Melaka were involved in this study. Result show that knowledge of historical background and attitude toward the preservation and conservation of tourist site is high. However, tourist practices to visit heritage site and historical site are relatively low especially for tourists visiting museums.

Keywords: Knowledge, attitude, practice, domestic tourist, Melaka.

Copyright @ 2019: This is an open-access article distributed under the terms of the Creative Commons Attribution license which permits unrestricted use, distribution, and reproduction in any medium for non-commercial use (NonCommercial, or CC-BY-NC) provided the original author and source are credited.

\section{INTRODUCTION}

Tourism is among the most important economic sectors contributing to development in many countries. The contribution of tourism to the country's development is diverse as being tool of economic growth, creating jobs, cultural preservation, environmental protection, peace and security and many others. Base on the World Tourism Organization (UNWTO) report, in 2017 the tourism sector contribute $10 \%$ of world Gross Domestic Product (GDP), $7 \%$ of world exports and $30 \%$ of services exports with a values of US\$ 1.6 trillion [1]. In Malaysia, tourism is the third largest contributor to the country's GDP in 2017 with a value of RM 201.4 billion or $14.9 \%$.

There are numerous studies covering various topics on Melaka as a cultural heritage site such as visitor behavior [2, 3], travel reason [4], preservation and conservation [5] and policy [6]. This study will examine the knowledge of domestic tourist towards Melaka's historical background, attitude towards the preservation and conservation and tourist practice during visiting the heritage and historical site around Melaka city using KAP (Knowledge, Attitude, Practices) survey. A KAP survey is representative study of a specific population to collect information on what is known, believed and done in relation to a particular topic [7]. KAP study tells us what people know about certain thing, how they feel and also how they behave [8]. Knowledge is understanding of or information about the subject that you get by experience or study, in this case, the historical background of Melaka and museum in Melaka. An attitude is a feeling or opinion about something or someone. In this study, focuses on preservation and conservation cultural heritage site in Melaka. Practice is something that is usually or regularly done,

\section{LITERATURE REVIEW Tourism}

The definition of tourism are varies and difficult to explain and it base on person (researchers), discipline or area of study (geography, economic, business and marketing, sociology and anthropology) and official definition (government and tourism organization). The difficulty can be seen in two aspect, firstly it is difficult to determine the boundaries of tourism as a distinct market (locals vs. visitors) and as resources (attractions, services and industries etc.) [9]. According to World Tourist Organization (UNWTO), 
tourism comprise the activities of person traveling to and staying in places outside their usual environment for not more than one consecutive years for leisure, business and others purpose. There are many type of tourism and can be classified according to various methods. Tourism can be classified base on destination either domestic or international, scale mass tourism or niche tourism, trip purpose either for personal or businesses as well as product such as natural environment, cultural heritage, health/medical, sport and many others.

Domestic tourism is a travel trip within the borders of a country while international tourism involves travelling beyond the boundaries of a country. As with international tourism, domestic tourism is increasingly important in contributing to the economic development of a country. In 2017, domestic tourism represented $73 \%$ of the total global tourism spend (US\$ 3971 billion) and in India and Brazil alone domestic contribution to Travel \& Tourism reached $94 \%$ and $87 \%$ respectively [10]. In Malaysia, domestic tourism expenditure in 2018 showing improvement over 2017 with a total expenditure value of RM 60.4 billion and mainly contribute by shopping, automotive fuel and food \& beverage [11]. Strong domestic tourism around the world is driven by a growing or sizeable middleclass population, an increase in spending power among domestic consumer, the sheers size of the country, government's initiative in promoting new location, and improvement transportation infrastructure and economic links between different internal regions [12].

\section{Cultural Heritage Tourism}

Cultural heritage tourism is tourism that involves visiting an historic and cultural site and participating in activities, which allow the tourist to experience that culture as it was in past and how it is today [13]. Heritage tourism is one of the most notable and widespread types of tourism and is among very oldest form of travel [14]. Heritage tourism activities include visiting museum or historical site, experience cultural environment, eating the local food or taking part in a festival. Ismagilova et al. has divide historical and cultural resources into six main type:

- Cultural, interest to work graphic and others arts form, to folklore, national trade, visit of festival.

- Historical, interest in country history, visit a historical monument and memorable places, thematic lectures on history.

- Archeological, interest in country archeology, visit a monument of antiquity, places of excavation.

- Ethnographic, interest on cultural of people, objects, subjects, and the phenomena of ethnic culture, a life, language, a suit, ethnic creativity.

- Ecological look, monument of landscape architecture [15].

\section{Melaka as a World Heritage Site}

Melaka together with Georgetown in Penang was awarded as World Heritage Site by UNESCO in 7 July 2008 at the meeting in Quebec, Canada. The selection is based on a long history of 500 years of development and its function as a cities connecting East and West in term in trading and culture exchange in the Straits of Melaka [16]. This award has becoming Malaysia's first cultural World Heritage Site (WHS) property. This declaration has further enhanced Melaka's status as cultural heritage destination in Malaysia. As a result, the number of tourist to Melaka has increase from year to year (see Table 1). In 2018, Melaka received a total of 17020098 tourist, an increase off 225630 compared to 16794468 registered in 2017. Of the total tourist arrival in $2018,66.6 \%$ were domestic tourist and the rest $33.4 \%$ were international tourist [17]. The number of tourist to Melaka in the first quarter (Q1) 2019 has increased by $17.49 \%$ compared to the same period last year. The state has recorded 4.79 million tourist arrival compared to 4.07 million within that time period. Domestic tourist remained the biggest contributors, with 3.4 million compared with 1.38 million foreign tourist and people from Selangor made up the largest number with $13.11 \%$ of total visitor to Melaka [18].

Table-1: Number of tourist arrival in Melaka (2012 2019)

\begin{tabular}{|c|c|}
\hline Years & Number of tourist arrival \\
\hline 2012 & 13711134 \\
\hline 2013 & 14312217 \\
\hline 2014 & 15032030 \\
\hline 2015 & 15736859 \\
\hline 2016 & 16282081 \\
\hline 2017 & 16794468 \\
\hline 2018 & 17020098 \\
\hline Q1 2019 & 4790000 \\
\hline
\end{tabular}

\section{METHODOLOGY}

\section{Data collection}

Data collection method used in this study is through a survey using questionnaire and convenience sampling was applied. Altogether 263 respondent involved in this study. The questionnaire was divided into five section involving respondent's background, travel information and three sections related to KAP survey.

\section{DATA ANALYSIS}

Data is processed using IBM Statistic Package of Social Sciences (SPSS) Version 25 software and statistic descriptive was applied.

\section{RESULT AND DISCUSSION Demographic Background}

Demographic information obtained from Table 1 shows that majority of respondent are female (61.2\%), young, ages between 20 to 29 years old (41.8\%), Malay 
Abd Rahman Roslan., Sch Bull, Dec 2019; 5(12): 809-814

ethnic group (77.6\%) and unemployment (housewife and student) $(39.5 \%)$. The largest number of respondents were from Selangor (41 respondents; $15.6 \%$ ), followed by Johor (34 respondents; $12.9 \%$ ), Federal Territory Kuala Lumpur (27 respondents; 10.3\%), Negeri Sembilan (26 respondents; 9.9\%),
Pahang (24 respondents; 9.1\%) and Perak (23 respondents; 8.7\%). The majority visitors visited Melaka for a holiday (184 respondents; 70\%), followed by working (19 respondents; 7.2\%), personal purpose (17 respondents; 6.5\%) and family matters (12 respondents; $4.6 \%)$.

Table-2: Respondent Demographic Characteristic

\begin{tabular}{|c|c|c|c|}
\hline Profile & Category & Frequency & Percentage \\
\hline \multirow[t]{2}{*}{ Gender } & Male & 102 & 38.8 \\
\hline & Female & 161 & 61.2 \\
\hline \multirow[t]{5}{*}{ Ages } & Below 20 years & 49 & 18.6 \\
\hline & $20-29$ years & 110 & 41.8 \\
\hline & $30-39$ years & 55 & 20.9 \\
\hline & $40-49$ years & 27 & 10.3 \\
\hline & 50 years and above & 22 & 8.4 \\
\hline \multirow[t]{4}{*}{ Race } & Malay & 204 & 77.6 \\
\hline & Chinese & 32 & 12.2 \\
\hline & Indian & 25 & 9.5 \\
\hline & Others & 2 & 0.8 \\
\hline \multirow[t]{4}{*}{ Occupation } & Government Sector & 56 & 21.3 \\
\hline & Private Sector & 66 & 25.1 \\
\hline & Self Employed & 37 & 14.1 \\
\hline & Unemployed & 104 & 39.5 \\
\hline \multirow[t]{6}{*}{ Monthly Income } & Below RM 1000 & 104 & 39.5 \\
\hline & RM 1000 - RM 1999 & 40 & 15.2 \\
\hline & RM 2000 - RM 2999 & 39 & 14.8 \\
\hline & RM 3000 - RM 3999 & 47 & 17.9 \\
\hline & RM 4000 - RM 4999 & 22 & 8.4 \\
\hline & RM 5000 and above & 11 & 4.2 \\
\hline \multirow[t]{15}{*}{ State of Origin } & Johor & 34 & 12.9 \\
\hline & Kedah & 17 & 6.5 \\
\hline & Kelantan & 16 & 6.1 \\
\hline & Melaka & 16 & 6.1 \\
\hline & Negeri Sembilan & 26 & 9.9 \\
\hline & Pahang & 24 & 9.1 \\
\hline & Perak & 23 & 8.7 \\
\hline & Perlis & 6 & 2.3 \\
\hline & Penang & 7 & 2.7 \\
\hline & Selangor & 41 & 15.6 \\
\hline & Terengganu & 14 & 5.3 \\
\hline & Sabah & 7 & 2.7 \\
\hline & Sarawak & 2 & 0.8 \\
\hline & F.T Kuala Lumpur & 27 & 10.3 \\
\hline & F.T Putrajaya & 3 & 1.1 \\
\hline \multirow[t]{6}{*}{ Purpose visit } & Holiday & 184 & 70 \\
\hline & Working & 19 & 7.2 \\
\hline & Personal & 17 & 6.5 \\
\hline & Family matters & 12 & 4.6 \\
\hline & Business & 6 & 2.3 \\
\hline & Others purpose & 25 & 9.5 \\
\hline
\end{tabular}

\section{Knowledge about Melaka}

Overall, respondents' knowledge about Melaka's historical background is high (see Table 3), where more than $95 \%$ of respondent answered 'Yes' to the question asked. $98.5 \%$ of respondent know that
Melaka is a historic city and $95.1 \%$ of respondent knew that Melaka was award as a World Heritage Site by UNESCO. Respondent also know well about Melaka's history where $95.1 \%$ knew that Melaka Sultanate is founded by Parameswara and $97.7 \%$ knew that Melaka 
Abd Rahman Roslan., Sch Bull, Dec 2019; 5(12): 809-814

was once colonized by Portugal and Dutch. Respondents also know that A'Famosa Fort has been built by Portuguese where $95.8 \%$ knew it. When asked about museum, 95.8\% respondents knew that museum is a cultural heritage product. However, only $74.1 \%$ respondent knew that there are over 20 museums in Melaka and $87.8 \%$ knew that Perbadanan Muzium Negeri Melaka (PERZIM) is the governing body of the museum in Melaka.

Table-3: Respondent knowledge about background of history and cultural heritage site in Melaka

\begin{tabular}{|l|c|c|}
\hline \multicolumn{1}{|c|}{ Item } & Yes & No \\
\hline \multicolumn{1}{|c|}{} & No. $(\%)$ & No. (\%) \\
\hline History is the series of past event. & $260(98.9)$ & $3(1.1)$ \\
\hline Melaka is a historic city in Malaysia. & $259(98.5)$ & $4(1.5)$ \\
\hline Melaka has been declared as a World Heritage Site by UNESCO. & $249(95.1)$ & $14(4.9)$ \\
\hline The Melaka Sultanate was founded by Parameswara. & $250(95.1)$ & $13(4.9)$ \\
\hline Melaka was once colonized by Portugal and Dutch. & $257(97.7)$ & $6(2.3)$ \\
\hline A'Famosa Fort is a historic landmark of Portuguese remains. & $252(95.8)$ & $11(4.2)$ \\
\hline The museum is a cultural heritage tourism product. & $252(95.8)$ & $11(4.2)$ \\
\hline There are over 20 museum in Melaka. & $\mathbf{1 9 5 ( 7 4 . 1 )}$ & $\mathbf{6 8 ( 2 5 . 9 )}$ \\
\hline $\begin{array}{l}\text { Perbadanan Muzium Negeri Melaka (PERZIM) is the governing } \\
\text { body of the museum in Melaka. }\end{array}$ & $231(87.8)$ & $32(12.2)$ \\
\hline
\end{tabular}

The high level of respondents' knowledge about Melaka is due to the historical subject taught at school have been discussing the history of Melaka from the Malay Sultanate to the Portuguese, Dutch and English colonizers. Therefore, the matter of Melaka's history is not a stranger to the respondent and knowing well about questions asked. In additional, majority respondents $(83.3 \%)$ had been to Melaka before, so they were familiar with the surrounding environment and information. Each cultural heritage product is also accompanied by a signboard that displays information about an event to the public.

\section{Attitude towards the preservation and conservation}

As well as knowledge, attitude respondent towards preservation and conservation cultural heritage site in Melaka indicates high percentages (see Table 4). 97.3\% respondents agreed that, Melaka need to be maintained as a World Heritage Site. Meanwhile, 93.9\% respondents agreed that cultural heritage site in Melaka need to be preserved and conserved and 95.8\% agreed that the task of preservation and conservation of cultural heritage site is a shared responsibility. Respondents also willing to participate and willing to contribute money in this effort with the percentage are $82.5 \%$ and $82.1 \%$ respectively. $83.7 \%$ of respondents are also willing to pay for visiting museum and other cultural heritage site.

Table-4: Respondent attitude towards preservation and conservation cultural heritage site

\begin{tabular}{|c|c|c|}
\hline & Yes & No \\
\hline & No. $(\%)$ & No. $(\%)$ \\
\hline I am interested in the topic of history & $209(79.5)$ & $54(20.5)$ \\
\hline I think Melaka needs to be maintained as a World Heritage Site. & $256(97.3)$ & $7(2.7)$ \\
\hline I think culture heritage site in Melaka need to be preserved and conserved. & $247(93.9)$ & $16(6.1)$ \\
\hline I am willing to participate to the preservation and conservation of cultural heritage site. & $217(82.5)$ & $46(17.5)$ \\
\hline I am willing to contribute money to the preservation and conservation of cultural heritage site. & $216(82.1)$ & $47(17.9)$ \\
\hline The task of preservation and conservation of a cultural heritage site is a shared responsibility. & $252(95.8)$ & $11(4.2)$ \\
\hline I will to pay to visit the museum and other cultural heritage site. & $220(83.7)$ & $43(16.3)$ \\
\hline
\end{tabular}

This demonstrated attitude indicates that domestic tourist really value the national cultural heritage site. And what is interesting is the attitude of the younger generation $(81.4 \%$ respondents are below 40 years old) who are concerned about the preservation and conservation of cultural heritage site in Melaka. Cultural heritage site need to be maintained for future generation as a form of teaching and learning.

\section{Practices}

As compared to the knowledge of the background of Melaka history and attitude respondents' towards the preservation and conservation of cultural heritage site, tourist practices show a relatively low percentage (see Table 5). Although $84.4 \%$ of the respondents stated the main reason they came to Melaka was to visit cultural heritage site, but only $65.4 \%$ stated that they visited more cultural heritage site than other tourist site and $64.3 \%$ stated that the first place when they arrived in Melaka were visit cultural heritage site. 
The percentage indicates a reduction when asked about visiting the museum. Only $57.4 \%$ respondent visit museum and $53.2 \%$ visited more than five museums while in Melaka. $73.8 \%$ of respondents examine every information displayed and $63.9 \%$ respondents just interested in taking picture during visiting cultural heritage site. When asked if they will come to Melaka again and propose to others to travel to Melaka, the percentage of both shows a high rate of $96.6 \%$ and $96.3 \%$ respectively.

Table-5: Respondent practice when visiting cultural heritage site

\begin{tabular}{|l|c|c|}
\hline & Yes & No \\
\hline & No. (\%) & No. (\%) \\
\hline I went to Melaka to visit cultural heritage site. & $222(84.4)$ & $41(15.6)$ \\
\hline The first place I visited in Melaka was a cultural heritage site. & $169(64.3)$ & $94(35.7)$ \\
\hline While in Melaka I visited more cultural heritage site than others tourist site. & $172(65.4)$ & $91(34.6)$ \\
\hline While in Melaka I visited museums. & $151(57.4)$ & $112(42.6)$ \\
\hline I visited more than five museums in Melaka. & $\mathbf{1 4 0 ( 5 3 . 2 )}$ & $\mathbf{1 2 3}(\mathbf{4 6 . 8})$ \\
\hline I'm just interested in taking pictures at a cultural heritage site. & $168(63.9)$ & $95(36.1)$ \\
\hline I examine every information displayed on a cultural heritage site. & $194(73.8)$ & $69(26.2)$ \\
\hline I often visit cultural heritage site while travelling. & $202(76.8)$ & $61(23.2)$ \\
\hline I will come back to Melaka & $254(96.6)$ & $9(3.4)$ \\
\hline I will tell somebody to visit Melaka & $253(96.3)$ & $10(3.8)$ \\
\hline
\end{tabular}

Local tourist practices that are not in line with the knowledge and attitude indicate the responsible parties such as Tourism Board and PERZIM should further promote to attract local young generation to visit the museum. Base and observation, it is found that only some museum can attract tourists to visit such as Melaka Sultanate Palace Museum, Melaka Maritime Museum and The Stadthuys (Red Building). Others museum, even in the hotspot location of tourism, are less attractive to tourist to visit. Tourists are just passing through the museum, although some museum does not charge any entrance fee.

\section{CONCLUSION}

In conclusion, despite the knowledge about history of Melaka and attitudes towards the preservation and conservation are high among respondent, the practices during visiting cultural heritage site in Melaka is relatively low especially visit museum. Almost haft of the respondent $(42.6 \%)$ did not visit museum and $63.9 \%$ of respondents just interested in taking picture (selfie). Effort is urgently needed to attract domestic tourist, especially younger generation to visit to museum. This is because the younger generation is a huge market for the tourism sector and they have a power on financial (spending power) as well as energy. Besides that, the industry can also focus on large groups rather than individuals to attract domestic tourist visiting the museum. Travel package deal involving museums visit can also be promoted extensively. The use of technologies such as simulation show and application can also be used to attract younger generation as they are particularly interested in the latest technology.

\section{ACKNOWLEDGMENT}

AIB2010/Tourism Geography Student, $1^{\text {st }}$ Semester, 2018/2019 Session

\section{REFERENCES}

1. World Travel \& Tourism Council. (2018). Domestic Tourism Importance and Economic Impact, WTTC, London.

2. Iskandar Hasan, T.A., Mohd Masdi, A.M., Emilia, A.M., \& Mohd Ridhuan. T.A. (2016). Customer Satisfaction Among Tourist Toward Malacca Museums in Malaysia, Journal of Applied Environmental and Biological Sciences, 6(6S), 4550.

3. Carol, B.C.T., Noor Rita, M.K., \& Faizah, A.R. (2014). Understanding Cultural Heritage Visitor Behavior: The Case of Melaka as World Heritage City, Procedia - Social and Behavioral Sciences, 130, $1-10$.

4. Fam, S.F., Mohd Taib, D., Norfaridatul Akmaliah, O., Fadhlur Rahim, A., Abdul Mutalib, M.A., Hamidah, N., \& Mohamad Fadzil Izad, A.S. (2017). Why Tourist Visit Melaka? Proceeding of 2017 China Marketing International Conference (CMIC 2017), Marketing Strategy in the Sharing Economy: Localization and Globalization, $785-$ 807.

5. Rahimah, A.R (2017). Heritage Conservation: Authenticity and Vulnerability of Living Heritage Site in Melaka State, Kajian Malaysia, 35(1), $39-$ 58.

6. Wan Hashimah, W. I. (2012) Sustainability of Building in Historic City of Malacca, Asian Journal of Environment-Behaviour Studies, 3(10), $57-69$.

7. World Health Organization. (2008). Advocacy, Communication and Social Mobilization for TB Control: A Guide to Developing Knowledge, Attitude and Practice Survey, WHO Press, Geneva.

8. Kaliyaperumal, K. (2004). Guideline for Conducting a Knowledge, Attitude and Practices (KAP) Study, AECS Illumination, 4(1), 7- 9. 
9. De Esteban, J., Cetin, G., \& Antonovica, A. (2015). Theory of Knowledge of Tourism: A Sociological and Epistemological Reflection, Journal of Tourismology, 1(1), 2 - 15.

10. World Travel \& Tourism Council. (2018). Domestic Tourism Importance and Economic Impact, WTTC, London.

11. Tourism Malaysia. (2019). Domestic Tourism Performance,

https://www.tourism.gov.my/media/view/domestictourism-performance-2018, retrieves on 19 July 2019.

12. Department of Statistic Malaysia. (2019). Press Release - Tourism Satellite Account 2018.

13. World Travel \& Tourism Council. (2018). Domestic Tourism Importance and Economic Impact, WTTC, London.

14. Jamieson, W. (1998). Cultural Heritage Tourism Planning and Development, Defining the Field and It's Challenges, APT Bulletin, 29 (3/4), 65.
15. Timothy, D.J., \& Boyd, S.W. (2006). Heritage Tourism in the $21^{\text {st }}$ Century: Valued Traditions and New Perspective, Journal of Heritage Tourism, $1(1), 1-16$.

16. Ismagilova, G., Safiullin, L., \& Gafurov, I. (2015). Using Historical Heritage as a Factor in Tourism Development, Procedia - Social and Behavioral Sciences, 118, 157 - 162.

17. UNESCO. (2019). Melaka and George Town, Historic Cities of The Straits of Malacca, whc.unesco.org/en/list/1223, retrieve on 19 July 2019.

18. The Star. (15 Mar 2019). State Achieves its Target of $17 \quad$ Million $\quad$ Tourists, https://www.thestar.com.my/metro/metronews/2019/03/15/state-achieves-its-target-of-17million-tourists/ retrieve on 19 July 2019.

19. The Star. (3 June 2019). More Tourist Flocking in Melaka, https://www.thestar.com.my/metro/metronews/2019/06/03/more-tourists-flocking-tomelaka/, retrieves on 19 July 2019. 